\title{
Sun exposure and sun protection habits in high school students from a city south of the country
}

\author{
Práticas de exposição e proteção solar em estudantes do ensino médio \\ de uma cidade do sul do país
}

Letícia Dupont $^{1}$

\author{
Denise Neves Pereira ${ }^{2}$
}

\begin{abstract}
BACKGROUND: Effective solar protection is an uncommon practice among young people, increasing the likelihood of sunburn, sunstroke and skin cancers. This fact is more significant in the south of Brazil, where the prevalence of white skinned population is larger, being more prone to sun damage.

ОвJестіvеs: To study the practices of sun exposure and sun protection in high school students from the city of Carlos Barbosa - RS. MEthoDS: Cross-sectional study involving 775 students, enrolled on the first half of 2010, who had signed the consent form. We used a non-identifiable, self-administered questionnaire, with questions about related topics. Statistical analysis was performed using Chi-square or Fisher exact and t-Student tests. The study was approved by the Research Ethics Committee under the number $2010-115 \mathrm{H}$.

REsults: Most students are exposed to the sun at the more critical periods, remaining exposed for more than an hour. Five hundred and seventy-six students (74,3\%) reported using sunscreen, but less than $10 \%$ did it during all months of the year. Female teenagers are most likely to use sunscreen $(\mathrm{p}<0.001)$ and to spend less time exposed to sunlight $(\mathrm{p}<0.001)$.

CONCLUSION: Most high school students from Carlos Barbosa had unsuitable sun exposure and sun protection habits, characterizing a high risk behavior for skin diseases. The existence of public programs for clarification of the risks to the population and the subsidization of sun protection products were suggested by these young people.

Keywords: Adolescent health; Solar radiation; Students; Sunscreening agents
\end{abstract}

Resumo: Fundamentos: A proteção solar efetiva é uma prática incomum entre os jovens, aumentando a probabilidade de queimaduras solares, insolações e cânceres de pele. Esse fato é mais significativo na Região Sul do Brasil, onde a prevalência da população branca é maior, sendo mais propensa aos danos causados pelo sol.

OвJETIVOS: Estudar as práticas de exposição e proteção solar em estudantes do ensino médio da cidade de Carlos Barbosa, RS. MÉTodos: Estudo transversal, envolvendo 775 estudantes matriculados no primeiro semestre de 2010, que tiveram o termo de consentimento assinado. Utilizou-se um questionário não identificável, autoaplicável, com perguntas abordando tópicos relacionados ao tema. $\mathrm{Na}$ análise estatística, foram utilizados os testes qui-quadrado ou exato de Fisher e o teste t-Student. O estudo foi aprovado pelo Comitê de Ética em Pesquisa sob o código 2010-115H.

Resultados: A maioria dos estudantes se expóem ao sol no horário mais crítico, permanecendo expostos por período superior a uma hora. Quinhentos e setenta e seis alunos (74,3\%) referiram utilizar protetor solar, mas menos de $10,0 \%$ deles o fazem durante todos os meses do ano. As adolescentes são as que mais usam filtro solar $(\mathrm{p}<0,001)$ e permanecem menos tempo expostas ao sol $(\mathrm{p}<0,001)$.

Conclusão: A maioria dos estudantes de ensino médio de Carlos Barbosa tem hábitos inadequados de exposição e proteção solar, caracterizando comportamento de risco para doenças de pele. A existência de programas públicos de esclarecimento dos riscos à população e o subsídio de produtos para a proteção solar foram sugeridos por esses jovens.

Palavras-chave: Estudantes; Protetores de raios solares; Radiação solar; Saúde do adolescente

Received on 17.01.2011.

Approved by the Advisory Board and accepted for publication on 02.02.11.

* Work performed at the Universidade Luterana do Brasil (ULBRA) - Canoas (RS), Brazil.

Conflict of interest: None / Conflito de interesse: Nenhum

Financial funding: None / Suporte financeiro: Nenbum

Medical degree awarded by the Lutheran University of Brazil (ULBRA), Canoas, RS, Brazil.

PhD in Paediatrics by the Universidade Federal do Rio Grande do Sul (UFRGS) - Neonatologist of the Hospital de Clínicas de Porto Alegre - Universidade Federal do Rio Grande do Sul (HCPA - UFRGS) Volunteer teacher in neonatology at the Medicine School of the Universidade Federal de Santa Catarina (UFSC) - Florianópolis (SC), Brasil.

(C)2012 by Anais Brasileiros de Dermatologia 


\section{INTRODUCTION}

Sunlight has important effects on the skin and it is associated with a variety of diseases. ${ }^{1,2,3}$ Despite the fact that most lesions caused by sun exposure only develop in adult life, most of the related damage is determined during childhood and adolescence. ${ }^{4-7}$

Exposure to ultraviolet (UV) radiation is considered the main risk factor for most skin cancers and sunlight is the main source of this type of radiation. ${ }^{8,9}$ The amount of damage caused by the UV rays depends on the intensity and the duration of the exposure and whether the skin is protected by clothing or sunscreen. Many studies also include exposure at early ages (for example, sunburns during childhood), as an additional risk factor. ${ }^{10-13}$

The American Cancer Society estimated that, in 2007 , more than a million cases of basal cell and epidermoid carcinomas and around 60 thousand cases of melanoma could be associated to UV radiation. ${ }^{14}$ Besides sun exposure, there are other risk factors for the development of skin cancers, like cutaneous phototype, eye and hair color, tendency to tan or to burn, and personal or family history of skin cancer. ${ }^{5}$

Adolescents constitute a vulnerable group to the harmful effects of the sun, both due to the cosmetic effects of tanning and the high frequency of outdoors sports activities. ${ }^{15-18}$ Effective sun protection, however, is an uncommon practice among the youth, a fact that increases the probability of sunburns, sunstroke and even future skin cancers in this subgroup of the population. ${ }^{19,20}$

This study aimed at assessing the sun exposure and sun protection habits of high school students from the city of Carlos Barbosa, and the results might serve as a background to prevention and health promotion strategies.

\section{MATERIAL AND METHODS}

The sample of this analytical, cross-sectional study was composed of high school students from the city of Carlos Barbosa, enrolled on the first semester of 2010, who consented to participate in the study. The calculation of the sample size was based on the results from a reference study performed with American students. ${ }^{5}$ The minimal number calculated was 323 students, considering a prevalence of $30 \%$ of sunscreen use, an alpha error of $5 \%$ and a power of $80 \%$.

The data was collected by the main researcher in three high school units in the city of Carlos Barbosa (Colégio Santa Rosa, Escola São Roque and Escola Elisa Tramontina). For the collection a non-identifiable, self-administered questionnaire was used, which was composed of sixteen multiple choice and five open questions, specifically designed for the present research. The questions included the following topics: sex, exposure and protection habits, cutaneous phototype, occurrence of adverse effects, existence of subjects that discussed sun exposure topics, family history of skin cancer and general knowledge about the topic. The answers were entered directly into data collection software.

A knowledge score was designed based on the assessment of the five risks related to sun exposure most quoted by the students: skin cancer, sunburns, sunstroke, spots and premature ageing. The minimal and maximal punctuation of each student could go from zero to five points. This way, the percentage of knowledge was calculated from the following formula: (number of quoted risks / 5) * 100 (Graph 1).

At data analysis absolute (n) and relative (\%) frequency tables were designed for all the variables of interest, except for the knowledge score, which was described by average, standard deviation, minimum and maximum. The chi-square or the Fisher exact tests were used for the categorical variables and the tStudent test for the continuous ones. The level of significance was 0,05 and the statistical program used was the SPSS (Statistical Package for Social Sciences) version 17.0.

This study was assessed and approved by the Research Ethics Committee of the Universidade Luterana do Brasil. The legal representatives of the teaching institutions were approached and their authorization was requested for their students to be interviewed, as well as for the parents or legal representatives of the students to sign the Free and Explained Consent Form.

\section{RESULTS}

775 adolescents participated in the study, 329 male $(42,4 \%)$ and 446 female $(57,6 \%)$. The majority of them had light hair $(58,9 \%)$ and eyes $(52,2 \%)$. The totality of the sample was composed by high school students from schools of the city of Carlos Barbosa - RS.

\section{SUN EXPOSURE AND PROTECTION HABITS Time of exposure}

Most students $(60,4 \%)$ reported exposure to the sun during the period between $10 \mathrm{am}$ and $4 \mathrm{pm}$, remaining exposed for more than one hour $(59,4 \%)$.

\section{Sunscreen use}

Five hundred and seventy six adolescents $(74,3 \%)$ reported the use of sunscreen, especially the females $(84,7 \%)$.

In terms of sun protection factor, 413 students $(53,3 \%)$ chose to use a SPF higher than 15 and 383 $(49,4 \%)$ reported only one daily application. 
Summer was the period of the year when more students reported the use of sunscreen $(63,7 \%)$, and $74,7 \%$ of them applied it to the whole body.

Table 1 shows the data pertinent to sunscreen use and the differences found between both sexes.

\section{Physical measures of sun protection}

Most students $(89,8 \%)$ reported using them, and the shirt was the most frequently quoted $(34,3 \%)$. This percentage increased when only the students that reported the use of sunscreen were analyzed, reaching a total of $91,5 \%$ use of association with physical measures.

\section{Sun exposure outcomes}

The prevalence of at least one episode of sunburn was $73 \%$. Adding to that, $73,7 \%$ of the total sample reported never having tanned or having difficulty in getting a tan. Among those interviewed, 132 male students $(40,1 \%)$ denied having a tan once, against only 65 female students $(14,6 \%)$.
An association between sunburn episodes and eye and hair color was also observed. Students who reported many episodes of sunburn are, mostly, those with light color eyes and hair. On the other hand, amongst the students with dark color eyes and hair the percentage of those who never burnt is the highest.

\section{Family history of skin cancer}

Most students $(88,0 \%)$ denied a positive history of skin cancer, and the highest number of positive cases $(12,7 \%)$ was observed amongst the girls.

\section{SUN EXPOSURE KNOWLEDGE}

Six hundred and forty nine students $(83,7 \%)$ denied the existence of a subject that approached the sun exposure subject. From those who answered positively, most said that that time was limited to only a few hours $(85,2 \%)$.

Skin cancer was the complication most quoted by the students $(81,5 \%)$, followed by burns $(53,3 \%)$, sunstroke $(15,9 \%)$, spots $(14,7 \%)$ and premature

TABLE 1: Sun exposure and sun protection habits according to sex*

\begin{tabular}{|c|c|c|c|c|}
\hline Variables & $\begin{array}{l}\text { Total Sample } \\
(n=775)(100 \%)\end{array}$ & $\begin{array}{l}\operatorname{Males}(n=329) \\
(42,4 \%)\end{array}$ & $\begin{array}{l}\text { Females } \\
(n=446)(57,6 \%)\end{array}$ & $\mathbf{p}$ \\
\hline \multicolumn{5}{|l|}{ Use of sunscreen } \\
\hline Yes & $576(74,3)$ & $198(60,2)$ & $378(84,7)$ & \multirow[t]{2}{*}{$<0,001$} \\
\hline No & $199(25,7)$ & $131(39,8)$ & $68(15,3)$ & \\
\hline \multicolumn{5}{|l|}{ SPF } \\
\hline None & $169(21,8)$ & $115(35,0)$ & $54(12,1)$ & \multirow[t]{4}{*}{$<0,001$} \\
\hline$<8$ & $19(2,5)$ & $10(3,0)$ & $9(2,0)$ & \\
\hline $8-15$ & $174(22,5)$ & $62(18,8)$ & $112(25,1)$ & \\
\hline$>15$ & $413(53,3)$ & $142(43,2)$ & $271(60,8)$ & \\
\hline \multicolumn{5}{|c|}{ Time of the year that SP is used } \\
\hline None & $79(10,2)$ & $55(16,7)$ & $24(5,4)$ & \multirow[t]{4}{*}{$<0,001$} \\
\hline Summer only & $494(63,7)$ & $217(66,0)$ & $277(62,1)$ & \\
\hline Summer and Winter & $139(17,9)$ & $41(12,5)$ & $98(22,0)$ & \\
\hline All seasons & $63(8,1)$ & $16(4,9)$ & $47(10,5)$ & \\
\hline \multicolumn{5}{|c|}{$\begin{array}{l}\text { Areas of the body that } S P \text { is } \\
\text { usually applied }\end{array}$} \\
\hline None & $80(10,3)$ & $57(17,3)$ & $23(5,2)$ & \multirow[t]{4}{*}{$<0,001$} \\
\hline Face only & $116(15,0)$ & $32(9,7)$ & $84(18,8)$ & \\
\hline Arms and face & $289(37,3)$ & $133(40,4)$ & $156(35,0)$ & \\
\hline Whole body & $290(37,4)$ & $107(32,5)$ & $183(41,0)$ & \\
\hline \multicolumn{5}{|l|}{ Daily applications } \\
\hline None & $140(18,1)$ & $94(28,6)$ & $46(10,3)$ & \multirow[t]{4}{*}{$<0,001$} \\
\hline One & $383(49,4)$ & $147(44,7)$ & $236(52,9)$ & \\
\hline Two & $199(25,7)$ & $71(21,6)$ & $128(28,7)$ & \\
\hline More than two & $53(6,8)$ & $17(5,2)$ & $36(8,1)$ & \\
\hline
\end{tabular}

*Statistical test applied: Chi-square 
ageing $(7,5 \%)$.

The time considered adequate for sun exposure was before 10 am and after $4 \mathrm{pm}$, quoted by $63,2 \%$ of the participants, the majority of them women $(70,0 \%)(\mathrm{p}<0,001)$.

When analyzing the knowledge about inadequate sun exposure, it was noted that the students who used sunscreen knew a higher number of risks when compared with those who did not use it, and they quoted the period between $10 \mathrm{am}$ and $4 \mathrm{pm}$ as the most adequate for exposure most frequently $(67,5 \%)(p<0,001)$.

Students with a positive family history for skin cancer could quote a higher number of risks from inadequate sun exposure in comparison to those with negative history, but this difference was not significant.

There was no significant association between the existence of subjects and the students' knowledge of sun exposure, not even in terms of the adequate period for this exposure $(p=0,064)$.

\section{Knowledge score}

The knowledge score was formed by the five most quoted risks by the students: skin cancer, sunburn, sunstroke, spots and premature ageing. The minimal and maximal punctuation form each student could go from zero to five points. This way, the knowledge percentage was calculated from the following formula: (number of risks quoted / 5) * 100 .

The average percentage of knowledge from the students was $34,6 \%( \pm 18,2)$ with a minimum of $0 \%$ and maximum of $80 \%$. These percentages indicate that the students quoted an average of 2 out of the five most quoted risks, and no student quoted the five risks. Sixty one students $(7,9 \%)$ did not quote any risk, 247 (31,9\%) one risk, 332 (42,8\%) two risks, 111 $(14,3 \%)$ three risks and $24(3,1 \%)$ quote four out of the five risks.

Chart 1 shows the students' knowledge score in relation to the risks of inadequate sun exposure.

\section{PUBLIC MEASURES SUGGESTED TO DECREASE THE HARMFUL EFFECTS OF SUN EXPOSURE}

The most quote suggestion by the students was based on the provision of information to the population $(57,3 \%)$, followed by donation or decrease of the prices of sunscreens (32,5\%). Environmental measures, like pollution control or building of covered areas for sports activities were quoted by $4,1 \%$ of the participants.

\section{DISCUSSION}

Skin cancer is the most incident neoplasia in various parts of the world, including in Brazil. ${ }^{21}$ The morbidity and mortality rates from this disease show an ascending tendency and can be attributed to various factors: early start of sun exposure, aesthetic valorization of tanning and recreational outdoors activities without adequate protection. ${ }^{21,22,23}$

Cokkinides et al. state that adequate sun protection is used by less than one third of the young people. Other data from the literature reinforce this result, reporting that adolescents spend excessive hours exposed to the sun, at inappropriate times and without adequate protection. ${ }^{4,7,17,22}$

This was the first study on sun exposure performed at the mountainous region of Rio Grande do Sul, and which approached, besides sun exposure habits, the knowledge from the students of the area. The chosen city, Carlos Barbosa, is located $100 \mathrm{~km}$ from the capital, Porto Alegre, and has approximately 25 thousand inhabitants. ${ }^{24}$ A great part of the population has German and Italian ancestry, peoples with characteristically fair skin and, therefore, with high risk for skin diseases.

Most of the participants know the adequate time for sun exposure (before 10 am and after $4 \mathrm{pm}$ ) but, still, more than half of them reported choosing the most harmful period to expose be exposed. This data agrees with other studies and can be justified, during the school holiday period, by social factors like

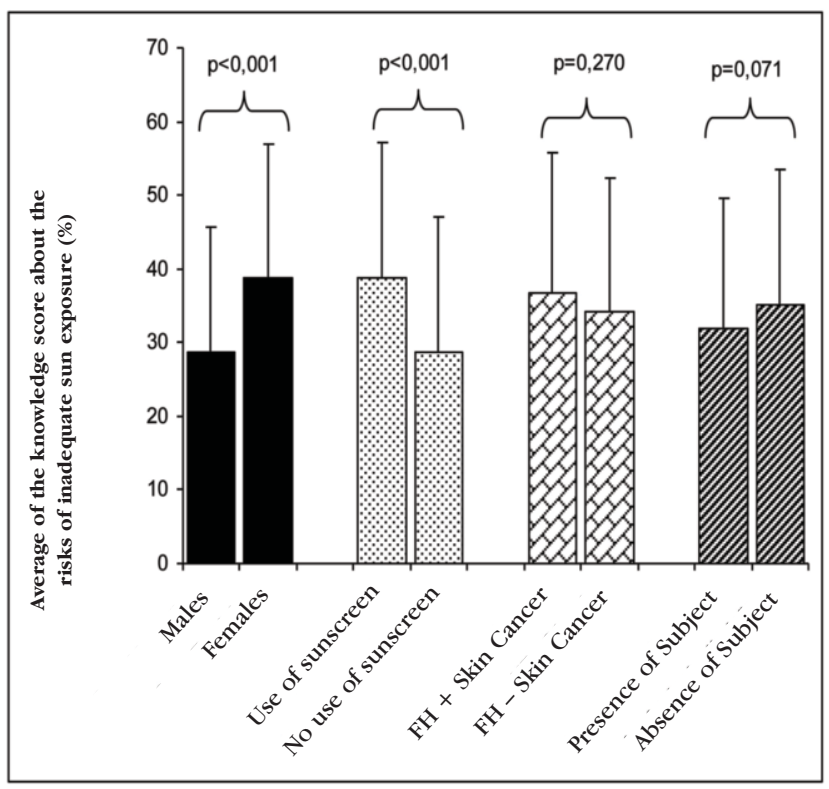

GrAPH 1: Knowledge score* about the risks of inadequate sun exposure according to sex, sunscreen use, family history of skin cancer and existence of subjects on the issue

*Knowledge score formed by the risks: skin cancer, sunburn, sunstroke, spots and premature ageing. The maximal total points that the student could get was five and the minimum zero. Calculation of the knowledge percentage: (number of risks quoted / 5) * 100. 
wanting to make the most of the holidays, have a late lunch and practice outdoors sports. ${ }^{7,15,18,22}$

In addition to that, despite the fact that most participants know the complications of inadequate sun exposure and the correct way to protect themselves, less than $10 \%$ reported applying sunscreen during all the months of the year. This lack of habit might be associated with the wrong concept that the sun is more harmful in summer, as could be observed in works by Fernandes et al. and Bakos et al. ${ }^{18,22}$

Almost all the adolescents reported the use of a physical sun protective measure, and the shirt was the main choice. This habit favors the concept of "effective sun protection", which consists on the use of sunscreen, physical measures of sun protection and strategies to avoid the sun, habits that might not be always adopted, but might be associated with the characteristic reaction of these adolescents who, during puberty, demonstrate a feeling of shame towards the body changes in evidence. ${ }^{7,15,25,26}$

As already shown by other studies, the female adolescents reported greater care with the prevention of sun damage, both by using sunscreen and by choosing the best time for their exposure. ${ }^{4,7,18,22}$ The vanity question and worries related to aesthetic issues can justify the prophylactic behavior among the girls.

Despite the reference to the use of sunscreen by the great majority of the adolescents, more than half of them reported having had some sort of adverse effect related to sun exposure, like sunburn or sunstroke. It can be deduced that this is due to inadequate use of photo protection or, yet, to the fact that the individuals feel protected and thus extend their exposure to the sun, as previously demonstrated. ${ }^{10,27,28}$

The prevalence of sunburn found was $73 \%$. This can be considered high when compared with the percentage of $48,7 \%$ found by Haack et al. ${ }^{10}$ in a study performed with youngsters aged between 10 and 29 years living within the urban area of Pelotas-RS. In the "X" city there are no high schools in the rural area, so the inhabitants move to schools located in the center of the city. Therefore, on the present study, students living on the rural areas were not excluded. This fact might explain the difference found, since a good part of the youngsters who live in those areas work in agriculture, under constant exposure to sunlight.

An association between sunburn and light color eyes and hair was found, as already mentioned in other studies. ${ }^{10,29}$ This finding is possibly related to the fact that these individuals have skin that is more sensitive to UV radiation (due to the lower melanin content), thus having a increased risk of sunburn. ${ }^{10,30}$

A positive family history for skin cancer was reported by $12,0 \%$ of the participants. Such percentage is similar to that found in skin cancer prevention campaigns by the Brazilian Society of Dermatology between 1999 and 2005, where the percentage was $14,2 \%{ }^{21}$

Public strategies aiming at propagating protective measures and information related to the effects of sun exposure were quoted by the students as the main strategy to decrease the harmful effects of the sun on the general population.

Approaching this question on the school environment still deserves more attention and dedication. ${ }^{16,18}$ Without doubt, the promotion of preventive aspects should start in class and, considering the importance of this issue on individual and collective health, the early and constant inclusion of related subjects must be stimulated. On the present study, most students denied the existence of subjects within this format. A significant association between the existence of such subjects and the students' knowledge was not found, probably due to the small number of students who reported having them and the small number of teaching hours dedicated to this subject, in the whole school.

\section{CONCLUSION}

Despite having adequate knowledge about sun exposure practices, most adolescents expose themselves excessively to the sun, at inadequate times and without effective protection.

Female adolescents demonstrated a higher preoccupation with sun damage, adopting preventive measures more frequently. The search for an ideal beauty can be associated with this fact. Anyway, the numbers found here are still beyond the desired ones, being only better when compared to those observed amongst the male participants.

Educational measures, especially focused on the risks of inadequate sun exposure, can help in approaching this situation. Well established instructions about "effective sun protection" must be part of the school curriculum, so that it is possible to avoid, with early intervention, the increasing number of skin cancers. $\square$ 


\section{REFERENCES}

1. Habif TP. Dermatologia clínica: guia colorido para diagnóstico e tratamento. 4 ed. Porto Alegre: Artemed; 2005.

2. Azulay RD, Azulay DR. Dermatologia. In: Filgueira AL. Fotodermatoses. 4 ed. Rio de Janeiro: Guanabara-Koogan; 2006. p.674-687.

3. Sampaio SAP, Rivitti EA. Dermatologia. In: Fotodermatoses. 3 ed. São Paulo: Artes Médicas; 2007. p. 843-856.

4. Szklo AS, Almeida LM, Figueiredo V, Lozana JA, Mendonça GAS, Moura L, et al. Comportamento relativo à exposição e proteção solar na população de 15 anos ou mais de 15 capitais brasileiras e Distrito Federal, 2002-2003. Cad Saúde Pública. 2007;23:823-34.

5. Cokkinides VE, Johnston-Davis K, Weinstock M, O'Connell MC, Kalsbeek W, Thun MJ, et al. Sun exposure and sun-protection behaviors and attitudes among U.S. youth, 11 to 18 years of age. Prev Med. 2001;33:141-51.

6. Harrison SL, Maclennan R, Speare R, Wronski I. Sun exposure and melanocytic naevi in young Australian children. Lancet. 1994;344:1529-32.

7. Costa FB, Weber MB. Avaliação dos hábitos de exposição ao sol e de fotoproteção dos universitários da Região Metropolitana de Porto Alegre, RS. An Bras Dermatol. 2004;79:149-55.

8. James WD, Berger TG, Elston DM. Andrews doenças da Pele - Dermatologia Clínica. In: Dermatoses Resultantes de Fatores Físicos. 10. ed. Rio de Janeiro: Elsevier; 2007. p. 21-49.

9. Wolff K, Johnson RA, Suurmond D. Fitzpatrick dermatologia - Atlas e texto. 5. ed. Rio de Janeiro: McGraw-Hill, 2006. p. 226-245.

10. Haack RL, Horta BL, Cesar JA. Queimadura solar em jovens: estudo de base populacional no Sul do Brasil. Rev Saude Publ. 2008;42:26-33.

11. Cancer.org [Internet]. American Cancer Society. Skin cancer - basal and squamous cell overview guide. [cited 2010 0ct 21]. Available: http://www.cancer.org/ Cancer/SkinCancer-BasalandSquamousCell/OverviewGuide/index

12. Cancer.org [Internet]. American Cancer Society. Skin cancer - melanoma overview guide. [cited 2010 Oct 21]. Available from: http://www.cancer.org/Cancer/ SkinCancer-Melanoma/OverviewGuide/index.

13. Parisi AV, Meldrum LR, Wong JC, Aitken J, Fleming RA. Effect of childhood and adolescent ultraviolet exposures on cumulative exposure in South East Queensland schools. Photodermatol Photoimmunol Photomed. 2000;16:19-24.

14. Inca.gov [Internet]. - Instituto Nacional de Câncer. Estimativa 2008. [acesso: 18 Out. 2011]. Disponível em: http://www.inca.gov.br/estimativa/2008/index.asp?link=conteudo_view.asp\&ID $=5$.

15. Vitor RS, Lopes CP, Trevisan MB, Meneses HS. Análise comportamental com relação à prevenção do câncer de pele. Revista AMRIGS. 2008;52:44-8.

16. Cázares JPC, Lepe V, Moscoso AG, Moncada B. Dosis de radiación ultravioleta em escolares mexicanos. Salud Publica Mex. 2003;45:439-44.

17. Cokkinides V, Weinstock M, Glanz K, Albano J, Ward E, Thun M. Trends in sunburns, sun protection practices, and attitudes toward sun exposure protection and tanning among US adolescents, 1998-2004. Pediatrics. 2006;118:853-64.
18. Fernandes VD, Marcomini AA. A comparação do nível de percepção sobre as causas do câncer de pele entre alunos do ensino fundamental e médio em duas escolas públicas do município de Cianorte - Paraná. Arq. Ciências da Saúde Unipar. 2006;10:151-4.

19. Molgó M, Castillo C, Valdés R, Romero W, Jeanneret V, Cevo T, et al. Conocimientos y hábitos de exposición solar de la población chilena. Rev Méd Chile. 2005;133:662-6.

20. Alberg AJ, Herbst RM, Genkinger JM, Duszynski KR. Knowledge, attitudes, and behaviors toward skin cancer in Maryland youths. J Adolesc Health. 2002;31:372-7.

21. Sociedade Brasileira de Dermatologia. Análise de dados das campanhas de prevenção ao câncer de pele promovidas pela Sociedade Brasileira de Dermatologia de 1999 a 2005. An Bras Dermatol. 2006;81:533-9.

22. Bakos L, Sukster E, Blanco LFO, Flamia CL, Oliveira EA, Amoretti RK, et al. Estudo comparativo sobre o conhecimento e comportamento de adolescentes e adultos frente à exposição solar. An Bras Dermatol. 1997;72:241-5.

23. Athas WF, Hunt William C, Key Charles R. Changes in nonmelanoma skin cancer incidence between 1977-1978 and 1998-1999 in Northcentral New Mexico. Cancer Epidemiol Biomarkers Prev. 2003;12:1105-8.

24. Carlosbarbosa.rs [Internet]. Prefeitura de Carlos Barbosa. A cidade. [acesso 31 Out 2010]. Disponível em: http://www.carlosbarbosa.rs.gov.br/site/index.php.

25. Wright MW, Wright ST, Wagner RF. Mechanisms of sunscreen failure. J Am Acad Dermatol. 2001;44:781-4.

26. Lopez FA, Campos Jr D. Tratado de Pediatria. Sociedade Brasileira de Pediatria. 2 ed São Paulo: Manole; 2009. p.349-61.

27. Davis KJ, Cokkinides VE, Weinstock MA, O'Connell MC, Wingo PA. Summer sunburn and sun exposure among US youths ages 11 to 18: national prevalence and associated factors. Pediatrics. 2002;110:27-35.

28. El sayed F, Ammoury A, Nakhle F, Dhaybi R, Marguery MC. Photoprotection in teenagers. Photodermatol Photoimmunol Photomed. 22:18-21, 2006.

29. Sampaio RNR, Cardoso NA. Câncer de pele no distrito federal: resultado da campanha de 1999. Brasília Med. 2000;37:81-6.

30. Hall HI, Saraiya M, Thompson T, Hartman A, Glanz K, Rimer B. Correlates of sunburn experiences among U.S. adults: results of the 2000 National Health Interview Survey. Public Health Rep. 2003;118:540-9.

How to cite this article/Como citar este artigo: Dupont L, Pereira DN. Sun exposure and sun protection habits in high school students from a city south of the country. An Bras Dermatol. 2012;87(1):90-5. 